UDC 669.7751

\title{
加圧熱水式硫黄製錬法の改良研究 $(\text { 第 } 2 \text { 報 })^{*}$
}

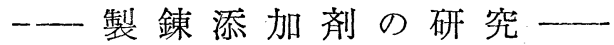

\author{
正会員末広建 介** \\ Study on Improvement of Sulfur Extraction with Autoclave Method (Part 2.) \\ Addition reagents for extraction-
}

Kensuke SUEHIRO

For making the extraction of sulfur easier by removing harmful amphiphilic minerals from the surface of sulfur, a study was made on addition reagents.

Effects of various addition reagents on each harmful mineral were tested in sealed glass tubes. The results are as follows:

i) Few surface active agents, except some nonionic, were effective, while some higher fatty acids and alcohols exhibited a good effectiveness.

2) Several petroleum oils were effective to some extent, but neither aromatic hydrocarbon nor pine oil showed effectiveness.

3) Very effective additions were obtained by mixing surface active agents with petroleum oils, and the author found that many harmful minerals were removed into water easily.

Further, the results of extraction tests of flotation concentrates using autoclave showed that this mixed addition reagent was also most effective as in the case of the sealed tube tests.

After a pilot test, this addition reagent was applied to industrial unit, making it possible to extract sulfur with a very high yield from the ores which hitherto seemed difficult to process.

\section{1. 緒言}

前報で述べたように硫黄鉱石中には種々の有害鉣物が 存在し製鍊を施害するが，もしなんらかの薬品を添加す ることによつてこれらの有害物を親水化し水中に移すこ とができれば，硫黄は容易矤集し製錬を内滑に行なう ことができるはずである。

実際においても古くより薬品を添加して製錬收率が向 上するといらいくつかの報告がある。例えば Lyamin ${ }^{1)}$ は少量の石油を添加し, Fridman2) は 粘土の存在に対 し水硝子や石油が有効であるとし Maslenitskii ${ }^{3}$ によ れば粘土に対して水硝子，昔性ソーダ，炭酸ソーダ等を 添加すると収率が増加するが，薬品の過剩は有害である という。また松島りは硫黃とカオリンあるいはベントナ イトとの種々の割合の混合試料に界面活性剂を加えて試 験し収率の増加を報告し, 岡本ら ${ }^{5}$ は界面活性剤, パル プ廃液などが硫黄の溶出摔を向上させると述べている。

特許面よりみると池辺 ${ }^{6}$ は沈殿鉱の処理に界面活性㓮 を, 保田 ${ }^{7}$ は硫黄と相互溶解力の大きい芳香族炭化水素

* 昭和35年11月29日受理

** 財団法人 野口研究所
またはその液状塩素化合物を, 中西ら ${ }^{8)}$ は明攀, 塩化バ リウムなど水中で多価陽イオンを与える化合物を，また 用川ら ${ }^{9}$ は燐酸ソーダ，水硝子等を界面活性剂と併用す ることを推奨している。

また工場によつては酸またはアルカリ性化合物を添加 して鉱液の $\mathrm{pH}$ を調節しているところむある。

しかしながらこれらの場合, 対象とされた鉱石の成分 についての考慮が十分でないので, ある種の鉱石に有効 とされた添加片も他種の鉱石には往々にして効果を発揮 しえないことがあつた。そこで著者はいろいろの鉱石に 対しても広く有効な添加剤を見出すため, まず硝子製封 管中で有害鉱物に対する種々の薬品の添加効果を試験し た。次いで浮選精鉱についてオートクレーブによる製鍊 試験を行ない，さらに工場装置による実用試験も行なつ た。

\section{2. 試料および試験方法}

試料としてはまず開発対象として研究していた沼沢, および生保内両鉱山の有害成分を用いた。これらは鉱石 よりベンゼンで分離したもので粘土ようの外観を呈して いるが, 沼沢は主として明攀石より，また生保内は主とし 
てカオリンよりなるものである。これらの試料に種々の 薬品を添加してまず有効な薬品を選出した。次いでカ才 リナイト(Drybranch)，ハロイサイト(Spruce Pine), タルク (海城), パイロフィライト (Robbins) などの粘 土鉱物，あるい注明攀石 (字久須)，石灰石（秩父），褐 鉄鉱（沼沢）などにも添加してその効果を検討した。

またこの他沼尻，武佐，潟沼等の諸鉱山の製鍊しがた いといわれている試料についても試験した。

添加剤として前記文献にみられるものを大別すると (1) $\mathrm{pH}$ 調節剤，（2)無機薬品，(3)界面活性剂, (4) 石油, （5）芳香族炭化水素またはその塩素化油などで，これら について追試するとともに新しい添加剤についても試験 した。このうち酸アルカリ, 無機薬品類の効果は対象鉱 物の種類によつて一様でなく，それのみによつて好結果 を期待できなかつたので，その詳細は省略した。

界面活性剂の種類は非常に多いが，アニオン，カチオ ン，非イオンおよび両性活性剤の各群のうちから代表的 なものを選んだ。これらはいずれも市販品をそのまま使 用し，特に精製しなかつたが，便宜上メ一カーのいう主 成分の名称を用いた。

石油類も市販品を用いたが，灯油，軽油などは特にパ ラフイン系炭化水素に富むものを選んだ。その他の薬品

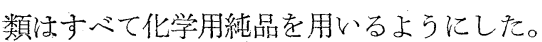

試験には前報と同じくガラス製封管を使用した。すな わち一定割合の硫黄と鉱物試料との混合物を封管に入 れ，乙杂に純水と適当量の添加剤を加えて溶封し，油浴 中で $140^{\circ} \mathrm{C}$ に加熱した後封管を取り出し，振温，舅掉な ぞの操作によつて添加剤の効果を次の 4 段階にわけた。

（1） E（非常に有効）：試料が親水性となり振壍 後，静置しただけで硫黄がたちまち凝集するもの。

（2） G(有効)：静置しただけでは硫黄は依然として 粒状のままで留まるが，覔姓すると有害物が分離し，完 全に凝集するようになるもの。

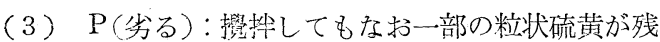
り，効果が不充分なもの。

（4） N(無効)：筧批しても硫黄が依然として粒状の ままで，効果が認められないもの。

\section{3．教管試験の結果於よび考察}

\section{$3 \cdot 1$ 界面活性剤}

界面活性剂は従来より添加剂として有効とされていた が，封管内で観察したところでは予想に反して有効なも のは少なかつた。

第1表に示すようにアニオン活性剤には一般に効果の ないものが多かつた。ただカリ石簽，ロート油など若干 の効果を示すものも亦つたが，これらも試料が変ると効 果がない場合があつた。カチオンおよび雨性活性剤も効
第 1 表 界面活性剤の効果

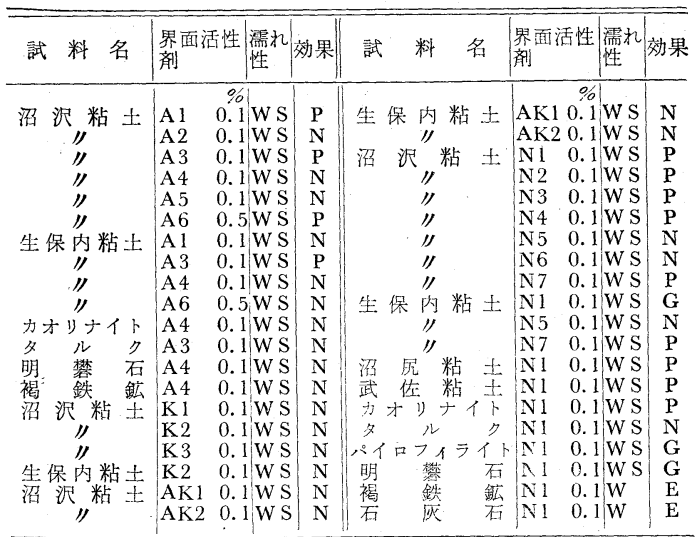

$\mathrm{E}$ : 非常に有効, $\mathrm{G}$ : 有効, $\mathrm{P}:$ 劣る, $\mathrm{N}$ : 焎效, $\mathrm{W} S$ : 両性, $\mathrm{W}:$ 親水性

・アニオン界面活性剂

A 1 カリ石铪

A2 フルキル硫酸塩(Teepol)

A3 硫酸化油(口ート油)

A4 $\mathrm{R}<>\mathrm{SO}_{3} \mathrm{NaR}=\mathrm{C}_{12}$

A5 $\operatorname{ROSO}_{3} \mathrm{Na} \quad \mathrm{R}=\mathrm{C}_{16}$

$\mathrm{A} 6$ パルプ廃液

ムカチオン界面活性放

$\mathrm{K} 1 \quad\left[\begin{array}{c}\mathrm{CH}_{3} \\ \mathrm{R}-\mathrm{N}_{-}-\mathrm{CH}_{2} \\ \mathrm{CH}_{3}\end{array}\right] \mathrm{Cl} \mathrm{R}=\mathrm{C}_{8 \sim 18}$

$\mathrm{K} 2\left[\mathrm{RO} \mathrm{CH}_{2}-\stackrel{\mathrm{N}}{\backslash}\right] \mathrm{Cl} \mathrm{R}=\mathrm{C}_{16}$

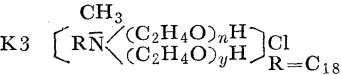

A两性界面活性隹

$\mathrm{A} \mathrm{K} l\left(\mathrm{C}_{2} \mathrm{H}_{4} \mathrm{OH}\right)_{3} \mathrm{NCH}_{2} \mathrm{COO}$

$\mathrm{AK} 2 \mathrm{R}\left\langle\left(\mathrm{C}_{2} \mathrm{H}_{4} \mathrm{O}\right)_{x} \mathrm{H}\right.$ $\mathrm{CH}_{2} \mathrm{COO}$

ム非イオン界面活性剂

$\mathrm{N} 1 \mathrm{R} \longrightarrow \mathrm{O}\left(\mathrm{C}_{2} \mathrm{H}_{4} \mathrm{O}\right)_{n} \mathrm{H} \quad \mathrm{R}=\mathrm{C}_{9} \quad n=20$

$\mathrm{N} 2 \quad \mathrm{RO}\left(\mathrm{C}_{2} \mathrm{H}_{4} \mathrm{O}\right)_{n} \mathrm{H} \quad \mathrm{R}=\mathrm{C}_{16} n=10$

N3 $\mathrm{RCOO}\left(\mathrm{C}_{2} \mathrm{H}_{4} \mathrm{O}\right)_{n} \mathrm{H} \mathrm{R}=\mathrm{C}_{17} \quad n=15$

N4 ポリオキシェキレン

N4 ソルビタン・モノステフレート $n=7$

N5 ソルビタン・モノステアレー

N6. $\mathrm{RNH}\left(\mathrm{C}_{2} \mathrm{H}_{4} \mathrm{O}\right)_{n} \mathrm{H} \quad \mathrm{R}=\mathrm{C}_{16} \quad n=15$

N7 $\mathrm{RCONH}\left(\mathrm{C}_{2} \mathrm{H}_{4} \mathrm{O}\right)_{n} \mathrm{HR}=\mathrm{C}_{15} \quad n=15$

第 2 表 脂肪酸，アルコール類枕よび フェノール類の效果

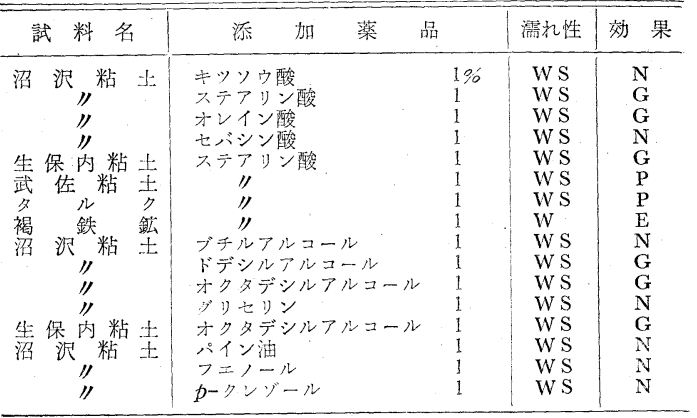

果が認められず，イオン性活性剂には概して有効なるの はなかつた。

非イオン活性剤はこれに比心かなりの効果寺示するの 
が多く，鉱物によつては完全に親水化されたものもあつ た。しかしどのような鉱石に対しても効果的であるとい えるものは見出されなかつた。

\section{$3 \cdot 2$ 脂肪酸およびアルコール類 ${ }^{10)}$}

これらはいずれも有極性構造をもち界面活性剂に類似 している。第 2 表に示したように低級の脂肪酸やアルコ 一ルでは効果がみられなかつたが，高級のものになると かなり有効であつた。これに対し両端に有極基のあるセ バシン酸，グリセリン等はいずれも無効であつた。

フェノール, クレゾール等も有極性構造をもつがいず れも無効であつた。

この他硫黄の浮遊選鉱に用いられるパイン油もテルペ ノールを含むがやはり効果がなかつた。

\section{$3 \cdot 3$ 石油および芳香族炭化水素油}

石油や芳香族炭化水素油も有効であるといわれている が，試験した結果は第 3 表にみられるように必ずしも有 効でない場合があつた。灯油，軽油，重油などはかなり 効果を示寸鉱石もあつたが，ぜんぜん効果のない鉱石も あつた。液体および固体のパラフイン類は効果がなかつ た。

トルエン，キシレン等の芳香族炭化水素油も効果が認

第 3 表 石油扣よび芳香族炭化水素油の効果

\begin{tabular}{|c|c|c|c|c|c|}
\hline 試 料 名 & 添 & 薬 & 品 & 濡水性 & 効 果 \\
\hline 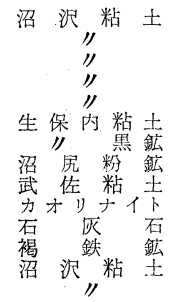 & 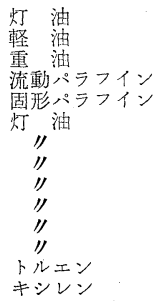 & & $\begin{array}{l}1 \% \\
1 \\
1 \\
1 \\
1 \\
1 \\
1 \\
1 \\
2 \\
2 \\
1 \\
1 \\
1 \\
1\end{array}$ & $\begin{array}{l}\text { WS } \\
\text { WS } \\
\text { WS } \\
\text { WS } \\
\text { WS } \\
\text { WS } \\
\text { WS } \\
\text { WS } \\
\text { WS } \\
\text { WS } \\
\text { WS } \\
\text { WS } \\
\text { WS } \\
\text { WS }\end{array}$ & $\begin{array}{l}\text { G } \\
G \\
G \\
\text { N } \\
N \\
\text { N } \\
\mathrm{P} \\
\mathrm{P} \\
\mathrm{N} \\
\mathrm{N} \\
\mathrm{N} \\
\mathrm{P} \\
\mathrm{N} \\
\mathrm{N}\end{array}$ \\
\hline
\end{tabular}

第 4 表 界面活性剤と石油との混合効果

\begin{tabular}{|c|c|c|c|c|c|}
\hline 試 料 名 & 界面 & 性 剤 & 灯 油 & 濡机 & 効 果 \\
\hline 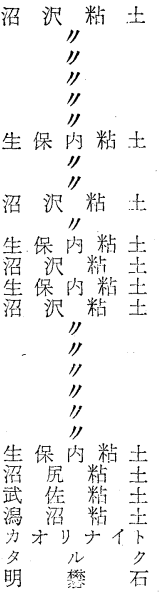 & $\begin{array}{l}\text { A1 } \\
\text { A2 } \\
\text { A3 } \\
\text { A5 } \\
\text { A5 } \\
\text { A6 } \\
\text { A1 } \\
\text { A3 } \\
\text { A4 } \\
\text { K1 } \\
\text { K2 } \\
\text { K1 } \\
\text { A K2 } \\
\text { A } 2 \\
\text { N1 } \\
\text { N2 } \\
\text { N3 } \\
\text { N4 } \\
\text { N5 } \\
\text { N6 } \\
\text { N7 } \\
\text { N1 } \\
\text { N1 } \\
\text { N1 } \\
\text { N1 } \\
\text { N1 } \\
\text { N1 } \\
\text { N1 }\end{array}$ & $\begin{array}{l}0.1 \% \\
0.1 \\
0.1 \\
0.1 \\
0.1 \\
0.5 \\
0.1 \\
0.1 \\
0.1 \\
0.1 \\
0.1 \\
0.1 \\
0.1 \\
0.1 \\
0.05 \\
0.05 \\
0.05 \\
0.05 \\
0.05 \\
0.05 \\
0.05 \\
0.05 \\
0.05 \\
0.05 \\
0.05 \\
0.05 \\
0.05 \\
0.05\end{array}$ & $\begin{array}{l}0.5 \% \\
0.5 \\
0.5 \\
0.5 \\
0.5 \\
0.5 \\
0.5 \\
0.5 \\
0.5 \\
0.5 \\
0.5 \\
0.5 \\
0.5 \\
0.5 \\
0.5 \\
0.5 \\
0.5 \\
0.5 \\
0.5 \\
0.5 \\
0.5 \\
0.5 \\
0.5 \\
0.5 \\
0.5 \\
0.5 \\
0.5 \\
0.5\end{array}$ & $\begin{array}{l}\text { WS } \\
\text { W S } \\
\text { W } \\
\text { WS } \\
\text { W S } \\
\text { W } \\
\text { WS } \\
\text { W S } \\
\text { W S } \\
\text { W S } \\
\text { W S } \\
\text { W S } \\
\text { W S } \\
\text { WS } \\
\text { W } \\
\text { W } \\
\text { W } \\
\text { W } \\
\text { W } \\
\text { W } \\
\text { W } \\
\text { W } \\
\text { W } \\
\text { W } \\
\text { W } \\
\text { W } \\
\text { W S } \\
\text { W }\end{array}$ & $\begin{array}{l}G \\
G \\
G \\
E \\
G \\
G \\
E \\
G \\
G \\
G \\
G \\
G \\
G \\
G \\
G \\
G \\
G \\
E \\
E \\
E \\
E \\
E \\
E \\
E \\
E \\
E \\
E \\
E \\
E \\
G \\
E\end{array}$ \\
\hline
\end{tabular}

められなかつた。

\section{4 界面活性剤之石油類の混用 ${ }^{11}$}

以上の試験結果では非イオン活性剤などある程度有効 なものが見出されたが，その場合でも多くは効果が不十 分であつた。そこで一層効果的な添加剤を見出す心゙く種 々検討を加えて行なつた結果, 界面活性剤と石油を混用 することによつてその目的を達成することができた。

その結果第 4 表にみられるようにアニオン,カチオン, 両性活性剤など単独使用ではほとんど効果が認められな かつたものでも, 石油類と混合して使用すると硫黄粒が かなり大きくなり，攪押すると容易に凝集するようにな るのが認められた。さらに非イオン活性剛の場合には一 層効果的で，ほとんどすべての鉱石が親水性となつて水 中に移行するので，振璗後硫黄が直ちに凝集してゅくの がみられるようになつた。

なおこの場合石油のような直鎖炭化水素の代りにキシ レン等の芳香族炭化水素を用いたところ，上述の効果は 認められなくなつた。

\section{5 考 察}

元来液体硫黄と水との間の界面張力はかなり大きい

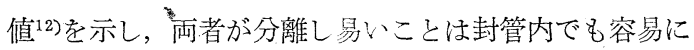
観察することができる。したがつてもし硫黄と水の両液 相間に介在する雨性の有害鉣物をなんらかの方法によつ て親水化してその界面より取り除くことができれば，製 錬は容易に進行するわけである。

前述のように製鍊添加郕として界面活性剂の有効性が 主張されているが，他方に新いて浮遊選鉱で怯鉱物表面 の疎水化に界面活性剤が使用されている。著者の実験に おいても非イオン活性剤を除いた他のイオン性の活性郕 のほとんぞが添加効果を示さなかつた。

界面活性冎が製錬効果をあげるのは液状硫黄と水との 間の界面張力が変化によるものであるとする説明 ${ }^{13}$ もあ るが，単にこれのみでは前述の相反する現象の理由を説 明することはできない。むしろこの場合には界面活性剂 のもつ親水基の強弱によつ下，両性鉱物の表面に打汀る 界面活性剂分子の配向が影響されるものとして考える方 が容易である。すなわち弱親水基からなる界面活性霍で 法踈水基の方が強く雨性鉱物汇引かれ，従つて親水基が 外側に向つて配向される結果, 両性鉱物の表面注親水化 される。これに反して強親水基をもつ場合にはこの方が 強く引かれ，蹯水基が外側に向つて配向せられることに

第 5 婊 界面活性剤の親水基の強さ

\begin{tabular}{|c|c|}
\hline 強親水基（電離基） & $\begin{array}{l}-\mathrm{COO}^{-} \mathrm{Na}^{+},-\mathrm{SO}_{3}^{-} \mathrm{Na}^{+},-\mathrm{OSO}_{3}-\mathrm{Na}^{+}, \\
\Rightarrow \mathrm{N}^{+}-\mathrm{Cl}^{-},-\mathrm{N}^{+} \mathrm{CH}_{2} \mathrm{COO}^{-}\end{array}$ \\
\hline 中位漞 水 基 & $-\mathrm{OH},-\mathrm{COOH},-\mathrm{CN},-\mathrm{NHCONH}_{2}$ \\
\hline 弱親水 基 & $\begin{array}{l}-\left(\mathrm{C}_{2} \mathrm{H}_{4} \mathrm{O}\right)_{n} \mathrm{H},-\mathrm{C}_{6} \mathrm{H}_{4} \mathrm{OCH}_{3},-\mathrm{COOCH}_{3}, \\
-\mathrm{CS},-\mathrm{CSSH}\end{array}$ \\
\hline
\end{tabular}


なり，製錬の目的とは逆に疎水化が

起ることになる。

界面活性剂のもつ親水基の強弱に ついては後藤 ${ }^{14}$ とよると第 5 表のよ らに類別されている。

このような評価によると非イオン 活性㓮は弱親水基よりなり，アニオ ン，カチオン，両性活性剤などはい ずれも電離性の強親水基をもつこと になる。したがって非イオン活性剤 に特に有効なものが見出され，イオ ン性の活性剤がほとんど無勃であっ た封管試験の結果をよく説明するこ とができる。

高級脂肪酸やアルコールなどがあ る程度の効果を示すのも，これらが 一 $\mathrm{COOH}$ または 一OH など比較 的弱い親水基をもち，非イオン活性 剂に類似した構造をもつためであると考えられる。これ に対して低級な脂肪酸やアルコールが効果を示さないの はこれらが水によく溶解することからも知られるよう に，疎水基が短かく親水基が相対的に強くなり，その配向 が逆になつたためと考穴らる。またフニノールやクレ ゾールについても同様な考え方が許されるものと思う。

石油類のような無極性物質の効果は上述の界面活性剂 などの場合とは異なる機作によるものと思われる。この 場合には 3 種の液相が存在するので，その間の鉱物粒子 の挙動は一層複雑になり，単に封管試験の結果からだけ では簡明な解答は得られない。これら 3 液相に対する有 害鉣物の濡れを検討したところ，石油と液体硫黄の場合 は石油中に移行し，石油と水の場合は両方に親和力を示 すのがみられた。それで封管中に石油を加えると，石油 を吸着した有害鉱物は硫黄よりはなれ，たがいに集合し ようとするので，攪挥すると硫黄は凝集しやすくなるの ではなからうか。ただ石油類も液体硫黄に若干溶解する ので，この分離は完全には行なわれないものと想像す る。これに対してトルエンのような芳香族炭化水素油は 製錬温度で液体硫黄に非常によく溶解し，少量の添加量 では独立した相としては存在し難いので，添加剤として の効果はないものと思われる。

以上の添加剤惊いずれも不満足な結果しか与えなかつ たが，界面活性剤に石油類を混合して使用すると，単独 では効果の認められなかったイオン性の界面活性剂でも 相当な効果を示すようになり，特に非イオン活性郕の場 合は非常に效果的で，鉱石が完全に親水化され水中に移 行するのがみられた。またこのように親水化された試料 を封管より取り出して分析すると， $2 \%$ 前後の石油が吸
着されているのが見出された。

それで界面活性剂を石油と混用すると，有害鉱物の疎 水面に石油が吸着して油層をつくるので, 界面活性剤は いずれもこの面に親油基を向けて配向されるようにな る。したがつて界面活性戍の親水基は外側に向うので, 鉱物表面の親水化が起り，また界面活性剂の種類による 影響も少なく，どの種類の界面活性剂でも一応効果を現 わすようになるのではないかと考える。

\section{4. オートクレーブによる製錬試験}

以上の封管試験は特殊な定性試験であるから，その結 果のみで添加剤の効果を即断することは危険であると 考えられる。そこでさらにオートクレーブを用いて実際 の浮選精鉱を処理して添加剂の効果を検討することにし た。まず $0.4 l$ の小型オートクレーブで種々の添加剤の 効果を試験して，封管試験の結果と比較した。次いで $50 l$ のオートクレーブによる中間試験，最後に $2 \mathrm{~m}^{3}$ の工 場装置による応用試験を行なつた。

試料は生保内および沼尻の鉱石を連続浮選機で処理し て得た精鉱で，第 6 表にみられるように，相当高品位の ものであるにもかかわらず，添加剤を用いない時はほと んど製品が得られないものであつた。

試験では鉱液濃度を50\%とし，所定量の添加剂を混合 してオートクレーブに装入した後, 直接水蒸気をオート クレーブ中に吹き込み $140 \sim 150^{\circ} \mathrm{C}$ に加熱する。この温 度で 20 分間挸找製錬を行なつた後，5 分間静置し硫黄の 凝集するのを待つてから，下方のバルブを開いて溶融硫 黄を流出させる。製錬残渣には粗粒状の硫黄が含まれる ので，微細部分を傾㳷分離して硫黄の㠜集程度を調べ 
た。

製錬試験は種々条件をかえて数多く行なつたが，その 要点を一括して第 6 表に示した。

表中の硫黄収率とは原料精鈗中の硫黄分に対する製鍊 生成物 (製品・残渣) 中の硫黄分の割合を示す。

この表にみられるように製錬試験でも封管試験の場合 と同様な傾向がみられた。界面活性剤のみを使用した場 合は非イオン性のものを除いて概して収率が低かつた。 高級脂肪酸やアルコール類はかなり有効で $85 \%$ 前後の収 率が得られた。また石油類は収率73\%である程度有効で あることがわかつた。

界面活性剂に石油を混合して使用すると，どの界面活 性剤でもそれを単独で使用した場合よりも収率が向上す るのがみられた。殊に非イオン活性剂の場合最も良い結 果を示し，収率が90\%余に達する場合もあつた。中間試 験では $94 \% の$ 高収率が得られた。

また工場における実用試験では攪找機のないオートク レーブであるにもかかわらず，連続12回の試験の平均収 率は88\%，中に壮93\%を超える場合もあつた。

残渣中の粗粒部はかなり品位が高く，その中の硫黄分 を浮選，分級などによつて回収することは比較的容易で あつた。したがつて $95 \%$ 以上の全収率を期待することは 必ずしも困難ではないと考える。

なお界面活性剤と石油との混合割合あるいはその添加 量などは処理す心゙き鉱石の種類によつてかなりり変化す る。またこれらの混合添加剤に助剤として無機塩類を加 えると一層効果的である場合もあつた。その他製鍊の諸 条件などの詳細については別の機会にゆずり今回は省略 した。

\section{5. 結 論}

加圧熱水式硫黄製鍊法を改良する目的で製錬添加剤の 研究を行なつた。まず有害鉱物の多くの試料について封 管法で種々の薬品の添加効果を試験した。その結果

（1）界面活性剤は有効であるといわれていたが，非 イオン活性剤を除いて他の活性剤はほとんど効果がなか つた。これは極性基の強弱によつて鉱物表面における界 面活性剤の配向が影響され, 弱親水基をもつ非イオン活 性剂では親水基が外側に向らので親水化が行なわれる が，電離性の強親水基をもつアニオン，カチオン，両性 活性剤などでは熱水基が内側に向い逆の結果になると考
えられる。

（2）高級脂肪酸，アルコールなどは非イオン活性剂 に類似した構造をもつており，ある程度の効果を示すも のがあつた。

（3）直鎖炭化水素を主成分とする石油類は不完全 ながらある程度効果があつたが，トルエンのような芳香 族炭化水素は効果がみられなかつた。このような無極性 炭化水素の効果は興味がありいろいろの機作が想像され るが，本実験の結果からだけでは適確な説明は得られな W。

（4）界面活性阂を石油類と同時に使用すると非常に 有効な添加剤が得られ，単独では効果が認められなかつ た電離性の活性剤もすへて効果を示すようになつた。殊 に非イオン活性剤の場合は鉱物の完全な親水化がみられ た。石油類を混用するとこれが鉱物表面に吸着されるの で，界面活性剤のもつ親油基がその表面に向つて配向さ れ易くなるためと考える。

（5）さらにオートクレーブによる浮選精鉣の製鍊試 験を行なつた結果，この場合も封管試験と同様な傾向が みられ，混合添加剂が最も良好な結果を与えた。

工場における実用試験においても，今まで製錬囯難と されていた鉣石を処理して平均 $88 \%$ ，中には93\%の高収 率を示す場合もあり，十分有効な添加剤であることが確 認された。

本研究において鉣石の浮遊選鉱，製鍊中間試験，工場 実用試験などに多大の便宜を与えられた日窒鉱業（株） をはじめ，いろいろの面より研究に御協力いただいた関 係各位の御厚情に感謝する次第である。

\section{文献}

1) Lyamin, N. F. : J. Appl. Chem. (U.S.S.R.) 9, 1400 (1936); C. A. 31, 2365.

2) Fridman, S. E.: J. Chem. Ind. (U.S.S.R.) 15, No. 12, 20 (1938) ; C. A. 33, 3081.

3) Maslenitskii, I. N. : lbid., 17, No. 2, 33 (1940); C. A. 29, 4903.

4) 松島知夫: 選研負報 (東北大), 9, 277 (1953).

5) 岡本 判：工化雑誌, $\mathbf{5 7}, 26$ (1954).

6) 池辺潼三郎：日特公：27-3053.

7) 保田雅夫：日特公 : 28-6603.

8) 中四伸次：日特公：31-5206；31-6303.

9) 田川 年: 日特公 : 31-6508.

10），11）著者：日特出願中

12），13）：松島知夫：選研䔡報，13，5；11 (1957).

14) 後藤廉平：実験化学绕座, 7, 120 (1956). 